\title{
The Effect of Using GeoGebra on Conceptual and Procedural Knowledge of High School Mathematics Students
}

\author{
Hutkemri Zulnaidi ${ }^{1}$ \& Effandi Zakaria ${ }^{1}$ \\ ${ }^{1}$ Department of Methodology and Educational Practice, Faculty of Education, Universiti Kebangsaan Malaysia, \\ Bangi, Selangor, Malaysia \\ Correspondence: Effandi Zakaria, Department of Methodology and Educational Practice, Faculty of Education, \\ Universiti Kebangsaan Malaysia, Bangi, Selangor, Malaysia. E-mail: effandi@ukm.my
}

Received: May 17, 2012 Accepted: June 1, 2012 Online Published: August 17, 2012

doi:10.5539/ass.v8n11p102 URL: http://dx.doi.org/10.5539/ass.v8n11p102

\begin{abstract}
The purpose of this study was to determine the effect of GeoGebra on conceptual and procedural knowledge of function. The study involved 124 high school students from Ujung Batu Rokan Hulu, Riau, Indonesia. A total of 60 students were in the treatment group and 64 students were in the control group. The data was collected using the conceptual and procedural knowledge test of function. The results showed significant differences between treatment and control groups $(\mathrm{t}=2.375, \mathrm{p}<0.05)$, in that the treatment group had significantly higher conceptual knowledge compared to control group. The treatment group differed significantly from the control group in procedural knowledge $(\mathrm{t}=2.215, \mathrm{p}<0.05)$. The findings of this study would provide schools administrator and teachers the opportunity to use GeoGebra software for teaching and learning mathematics. The education ministry is expected to provide training for teachers to improve their skills in the use of GeoGebra.
\end{abstract}

Keywords: GeoGebra, conceptual knowledge, procedural knowledge, function

\section{Introduction}

The use of computers as a mathematics teaching aid can improve student motivation and increase their confidence (Sivin-Kachala \& Bialo, 2000). Nowadays, many software programs can be used to help students be more responsible for their own learning through creative and interesting exploration. Teaching and learning software are now increasingly important, especially in the subject of calculus (Ahmad Fauzi et al., 2009). Mathematical software, such as MathCAD, Maple, Autographs, and the like, has been widely used in the teaching and learning mathematics. Many studies have been conducted on the effects of using various software packages on teaching and learning of mathematics. However, the existing studies show inconsistent results.

When teaching mathematics, teachers use traditional methods that are commonly used to explain mathematical concepts and procedures. Teachers should also consider using technology that is useful and beneficial to students. Teaching should be planned so that the process of teaching and learning will run smoothly and effectively. Positive approach will produce a positive and effective result (Ager, 2000). Teachers must be willing to accept change and make technology a reality in the classroom. Teachers who are entrusted to educate the nation's future leaders should give serious attention to the use of technology in teaching and learning. Educators should strive to ensure that mathematics is interesting for students to learn while focusing on important concepts in mathematics. In addition to building skills in mathematics, learning using technology can have a positive long-term effect on students. By giving them the opportunity to learn and understand mathematics through technology, students are provided with knowledge to compete and function in the high-tech world. It is the responsibility of educators to provide a bright future for students in the face of the world that depends on Mathematics, Science, and Technology (Furner \& Marinas, 2007).

Selden and Selden (1992) stated that the concept of function involves a combination of many different branches of modern mathematics. In order to help students achieve success in higher mathematics, students need to have a deep mental concept of function. Calculus is a starting point of a higher mathematical thinking while functions are key concepts in calculus (Vinner, 1992). Many studies reported that function is one of the topics that are difficult to learn by students (Bell, 2001; Jensen, 2009; Teachey, 2003). Ratliff (2009) also reported that 
composite functions and inverse functions are also difficult for students to grasp. Hiebert and Le Fevre (1986) stated that conceptual knowledge is the knowledge of network, which forms a vital link with the information provided. They also defined two parts of procedural knowledge, (a) a knowledge of mathematical symbols and (b) knowledge of algorithms or rules used in solving mathematics tasks.

Currently, the inclusion of technology in the classroom has been widespread in rural and urban areas. Therefore, in order to help educators integrate technology in teaching and learning mathematics, teachers can use GeoGebra as one of the alternatives. This software can be downloaded from the official website of GeoGebra free of charge and is able to work across various platforms, including Windows, Macintosh, Linux, and Unix (www.geogebra.org). The most interesting aspect of GeoGebra is a virtual community of users who frequently contribute to the free teaching materials produced. These tutorials cover the subject of an integer, distribution, linear equations, coordinate systems, angles, triangles, the formula space, transformation, symmetry, circles, Bezier curves, quadratic equations, matrix transformation, parametric functions, polynomial functions, derivatives, integrals, complex numbers, line and space, vector functions, and others.

GeoGebra can be used to teach Geometry, Algebra, and Calculus (Antohe, 2009; Hutkemri \& Effandi, 2010; Rincon, 2009). GeoGebra effectively disseminates knowledge that includes planning, delivery, guidance, and evaluation that aims to spread the knowledge or skills to students (Hutkemri \& Effandi, 2010). GeoGebra software has the potential to help teachers implement teaching test conjecture on geometry, algebra, and calculus. Therefore, this study considered three theories of teaching and learning, i.e., cognitive, behaviorist, and constructivist theory. Cognitive theory states that learning is an organizing aspect of cognition and perception to gain an understanding (Ausubel, 1986; Piaget, 1978). In this theory, internal thought processes that occur during the learning process influence the behavior of a person determined by the perception and understanding of the situation relating to the purpose and behavior change. Gagne et al. (1992) identified features of behavioral learning theory that are able to attract the attention of teaching students through a clear teaching aids, including attractive colors and graphics as well as the existence of two-way communication. Constructivism is a process of knowledge formation. This formation must be done by students themselves. Therefore, students should actively engage in activities, active thinking, organizing, and making sense of concepts learned. Therefore, this theory emphasizes active participation of students in developing their own knowledge. Learning can be achieved effectively and efficiently using appropriate learning strategies. Appropriate learning strategies maximize learning achievement (Slameto, 2003). Therefore, the researcher would like to explore the conceptual and procedural knowledge of students using GeoGebra. This study aims to identify the effect of using GeoGebra on conceptual and procedural knowledge of mathematics among secondary school students. The study also assesses the views of students on the use of GeoGebra software in teaching and learning about functions. The objectives of the study are as follow:

(a) To compare the conceptual knowledge of students in treatment and control groups.

(b) To compare the procedural knowledge of students in treatment and control groups.

\section{Materials and Method}

This study used a quasi-experimental non-equivalent pretest and post-test control group design (see Table 1). This study was conducted on students in two State High Schools (SMAN) 1 Ujung Batu, Riau, Indonesia.

Table 1. Experimental design of the study

\begin{tabular}{lccc}
\hline Group & Pre Test & Method & Test Post \\
\hline Treatment Group & $\mathrm{O}_{1}$ & $\mathrm{X}_{1}$ & $\mathrm{O}_{2}$ \\
Control Group & $\mathrm{O}_{1}$ & $\mathrm{X}_{2}$ & $\mathrm{O}_{2}$ \\
\hline
\end{tabular}

In this design, $\mathrm{O}_{1}$ and $\mathrm{O}_{3}$ represent the pre-test for treatment group and control group, while $\mathrm{O}_{2}$ and $\mathrm{O}_{4}$ represent the post-test for treatment group and control group. $\mathrm{X}_{1}$ and $\mathrm{X}_{2}$ represent teaching methods given to the two treatment groups, GeoGebra software group and a traditional teaching methods group. Both groups were given the same pre-test before and after the completion of the study. Both groups completed post-tests after being exposed to one of the teaching methods. Pre-test was used to assess similarities between groups. The researcher implemented GeoGebra in the treatment group and the traditional methods of teaching in the control group.

The sample consisted of students from two high schools in Riau Indonesia. A total of 124 students were involved in this study. Sixty students (60) were assigned to the treatment group and 64 students were assigned to the control group. The same teacher taught each group.

The researcher developed the instrument to measure conceptual and procedural knowledge and a subject 
specialist verified the content. Scoring of the conceptual and procedural knowledge of students was done according to Teachey (2003). The reliability index of the conceptual knowledge test was 0.82 , while the reliability index of the procedural knowledge test was 0.83 . This shows that the reliability of the conceptual knowledge test and procedural knowledge test of function are at very high levels (Baba, 1997).

\section{Results}

\subsection{Pre-Test Analysis}

To explain the obtained results, statistical testing was performed using the Kolmogorov-Smirnov normal test. The significance level of the pre-test scores for the treatment group and for each control group were greater than 0.05 , indicating that the distribution of pre-test scores is normal (Table 2).

Table 2. Normality test for pre-test conceptual and procedural knowledge of function

\begin{tabular}{ccccc}
\hline \multirow{2}{*}{ Knowledge } & \multicolumn{3}{c}{ Kolmogorov-Smirnov } & Sig \\
& Group & Statistical & df & $0.200^{*}$ \\
Conceptual & Treatment & 0.095 & 60 & $0.200^{*}$ \\
& Control & 0.087 & 64 & $0.200^{*}$ \\
Procedural & Treatment & 0.087 & 60 & $0.200^{*}$ \\
& Control & 0.089 & 64 & \\
\hline
\end{tabular}

Independent t-test was conducted to compare the treatment and control group. The results indicate no difference between the treatment and control groups in conceptual and procedural knowledge of mathematics before the initiation of the study (conceptual knowledge, $\mathrm{t}=0.077, \mathrm{p}>0.05$ and procedural knowledge, $\mathrm{t}=-0.363, \mathrm{p}>0.05$, see Table 3). Accordingly, equality of groups at baseline suggests that it is appropriate to conduct the experiment and subsequently compare the conceptual and procedural knowledge of mathematics on the topic of function.

Table 3. Differences between groups in pretest scores on conceptual and procedural knowledge

\begin{tabular}{lllllll}
\hline Knowledge & Group & $\mathrm{N}$ & Min & $\begin{array}{l}\text { Standard } \\
\text { deviation }\end{array}$ & Value of t & Sig. \\
\hline Conceptual & Treatment & 60 & 5.12 & 2.865 & 0.077 & 0.939 \\
& Control & 64 & 5.08 & 2.698 & & \\
Procedural & Treatment & 60 & 4.63 & 2.743 & -0.363 & 0.717 \\
& Control & 64 & 4.81 & 2.748 & & \\
\hline
\end{tabular}

\subsection{Post-Test Analysis}

\subsubsection{Differences between Groups in Conceptual Knowledge of Function}

Independent t-test analysis showed significant differences between groups in student mathematical conceptual knowledge, $\mathrm{t}=2.375, \mathrm{p}<0.05$, (see Table 4). This indicates that students' in the treatment group had a higher conceptual knowledge compared to the control group, rejecting the null hypothesis.

Table 4. Differences in conceptual knowledge at post-test

\begin{tabular}{cccccc}
\hline The concept of knowledge & $\mathrm{N}$ & Min & $\begin{array}{c}\text { Standard } \\
\text { deviation }\end{array}$ & Value of t & Sig. \\
\hline Treatment & 60 & 14.50 & 2.721 & 2.375 & 0.019 \\
Control & 64 & 13.39 & 2.479 & & \\
\hline
\end{tabular}

\subsubsection{Differences between Groups in Procedural Knowledge of Function}

Independent $\mathrm{t}$-test analysis showed significant difference between groups in procedural knowledge of mathematics, $\mathrm{t}=2.215, \mathrm{p}<0.05$ (see Table 5). This indicates that students in the control group had a higher procedural knowledge compared to the treatment group, rejecting the null hypothesis.

Table 5. Differences between groups in procedural knowledge at post-test

\begin{tabular}{cccccc}
\hline Procedural knowledge & $\mathrm{N}$ & Min & $\begin{array}{c}\text { Standard } \\
\text { deviation }\end{array}$ & Value of t & Sig. \\
\hline Treatment & 60 & 14.90 & 2.153 & 2.215 & 0.029 \\
Control & 64 & 14.03 & 2.211 & & \\
\hline
\end{tabular}




\section{Discussion}

The quantitative findings showed significant differences between the treatment and control groups in conceptual knowledge of functions. Students in the treatment group had higher conceptual knowledge at post-test compared to the control group. The findings of this study indicated that teaching using GeoGebra could improve conceptual knowledge of students. The use of graphical representation may make it easier for students to learn about the topics of function. Consistent with research conducted by Clark (2006), the conceptual approach to teaching secondary school students using graphing calculator indicated that the treatment group showed significantly higher growth of conceptual understanding of the topic of function compared to the control group. The study provided evidence that the use of technology can influence students' ability to solve problems (Bell 2001). The findings also revealed students in the treatment group had higher procedural knowledge compared to the control group. This suggests that GeoGebra can also enhance procedural knowledge. Such technology helps in understanding the relationship between conceptual and procedural knowledge. In sum, using GeoGebra in the teaching and learning of mathematics could increase conceptual as well as procedural knowledge of students.

\section{Conclusion}

This study provides recommendations to encourage the use of technology in the teaching and learning of mathematics. The findings of this study can be used to encourage secondary school teachers to use GeoGebra in their math classes. Furthermore, schools can utilize these results to provide support and training to teachers on the use GeoGebra in teaching mathematics.

\section{References}

Ager, R. (2000). The Art of Information and Comnunications Technology for Teachers. London: David Fulton Publishers.

Ahmad Fauzi Mohd Ayub, Tengku Mohd Tengku Sembok, \& Wong Su Luan. (2009). The use of computer in teaching and learning of Mathematical calculus among diploma students: Evaluation on the TEMACC package. Cited in Ahmad Fauzi Mohd Ayub and Aida Suraya Md. Yunus. Mathematics education and application of technology. pp 274 - 300. Putra University of Malaysia.

Antohe, V. (2009). Limits of Educational Soft "GeoGebra" in a Critical Constructive Review. Annals. Computer Science Series. 7th Tome 1st Fasc. Anale. Seria Informatica. Vol. VII fasc. 1 - 2009.

Ausubel, D. P. (1986). A cognitive view. Educational Psycology. New York: Holt, Rinehart and winston.

Baba, A. (1997). Research Statistic in Education and Social Science. Bangi: Universiti Kebangsaan Malaysia

Bell, C. J. (2001). Conceptual understaning of function in a multi-representational learning environment. Dissertation Doctor of philosophy Presented to the Faculty of the Graduate School of the University of Texas at Austin.

Clark, M. D. (2006). A conceptual approach teaching functions to middle school students. Master Thesis. Californnia State University Dominguez Hills.

Furner, J. M., \& Marinas, C. A. (2007). Geometry Sketching Software for Elementary Children: Easy as 1,2,3. Eurasia Journal of Mathematics, Science \& Technology Education, 3(1), 83-91.

Gagne, R., Briggs, L., \& Wager, W. (1992). Principles of instruction design (4th ed.). Texas: HBJ College Publisher.

Hibert, J, \& Lefevre, P. (1986). Conceptual and procedural knowledge in mathematics: An introductory analyis. In J. Hibert (Ed.), Conceptual and procedural knowledge: The case of mathematics (pp. 1-23). Hillsdale, NJ: Lawrence Erlbaum Associates.

Hutkemri, \& Effandi Zakaria. (2010). GeoGebra Software in Mathematics. Proceeding International Seminar Comparative Studies in Education System Between Indonesia and Malaysia. Bandung: Rizqi Press.

Jensen, T. A. (2009). A study of the relationship between introductory calculus students' understanding of function and their understanding of limit. Dissertation Doctor of philosophy. Montana State University.

Piaget, J. (1978). Success and understanding. Cambridge. MA: Harvard University Press.

Ratliff, B. K. (2009). Student Understanding of Function Composition and the Effect of Dynamic Visualization. Dissertation. Faculty of the Curry School of Education, University of Virginia.

Rincon, Luis F. (2009). Designing Dynamic and Interactive Applications Using Geogebra Software. Kean University. ERIC Full text and Thesis. 
Selden, A., \& Selden, J. (1992). Research perspective on conceptions of functions: summary and overview. In Harel, G., \& Dubinsky, E. (Eds.), The concept of function: aspects of epistemology and pedagogy (pp. 1-16). Washington DC: Mathematical Association of America.

Sivin-Kachala, J., \& Bialo, E. R. (2000). Research Report on the Effectiveness of Technology in Schools (7th ed.). Washington, D.C.: Software Information Industry Association.

Slameto. (2003). Learning and their factors. Jakarta. Rhineka Cipta.

Teachy, A. L. (2003). Investigation in conceptual understanding of polynomial function and the impact of mathematical beliefs systems on achievement in an accelerated summer program for gifted students. $\mathrm{PhD}$ Dissertation. University of North Carolina.

Vinner, S. (1992). The Function Concept as a Prototype for Problems in Mathematics Learning. In G. Harel, \& E. Dubinsky (Eds.), The Concept of Function: Aspects of Epistemology and Pedagogy (pp. 195-214). MAA. 